\title{
Navigating the Field of Contemporary Political Consumerism: Consumer Boycott and Consumer Buycott Vistas
}

\author{
May Aung \\ University of Guelph \\ Juan Wang \\ University of Guelph \\ Xinyue Zhang \\ Explorer Research
}

The aim of this paper is to understand and compare the two growing forms of contemporary political consumerism, boycott and buycott, in competitive marketplace. We used an existential-phenomenology approach and conducted 15 in-depth interviews. This resulted in 75 boycott and buycott consumption experiences and 229 pages of interview transcripts. Content analysis shows that consumers perceive boycott and buycott as two distinct actions. They differ in terms of goal orientation (avoidance vs. approach), ease of participation, as well as consumer information search and learning style. Further, we identify similar and unique motivational factors for boycott and buycott. Specifically, we show motivations within individual context, boycott activity context, and societal context. Strong evidence indicates that, within individual context, motivations relating to self-enhancement, required resources and associated costs are important for both boycott and buycott consumerism. Motivations within societal context also seems to be relevant for both types of consumerism. However, only the motivations within the boycott activity context were found in this study. Theoretical and managerial implications are also discussed.

Keywords: political consumerism, boycott, buycott, in-depth interview

\section{INTRODUCTION}

Consumers believe their consumption decisions have the potential to improve companies' practices on corporate social responsibility (Crane et al., 2008; Shaw et al., 2006). Prior literature refers to the consumption decision with the goal of changing objectionable institutional and market practices as political consumerism (Micheletti, 2003, p.2). In this paper, we try to better understand and distinguish the two most common forms of political consumerism in the competitive marketplace: consumer boycott and buycott.

Consumer boycott describes consumer intent on punishing companies for irresponsible behaviours (Baek, 2010). Recent examples include the boycott of Coca-Cola for its misconduct in Columbus, the anticonsumption of Voopoo (a vape company) on Twitter, and PETA calls for a boycott of Canada Goose in 2018 for their unethical animal use. On the other hand, consumer buycott is about the intent on supporting 
companies that act responsibly (Micheletti, 2003; Micheletti \& Boström, 2014; Neilson, 2010; Stolle \& Micheletti, 2013), such as the Buy American campaign that encourages consumer purchase of "made in America", as well as the popular temporary purchase flashmobs organized by consumer activists (Hoffmann \& Hunter, 2012). While both boycott and buycott consumerism are driven by concerns related to the social, environmental, and welfare of other people, different values held by individuals may determine which drivers are more or less likely to predict boycott and/or buycott behaviour (Hoffmann et al., 2018; Newman \& Bartels, 2011; Shah et al., 2007; Neilson \& Paxton, 2010). To date, however, most of the existing literature on political consumerism has mainly focused on boycott, only a few studies have distinguished boycott from buycott (e.g., Stolle et al., 2005; Strømsnes, 2009). Thus, the objective of this paper is to advance the knowledge on political consumerism by exploring and differentiating consumer boycott and buycott behaviours. Specifically, we would like to focus on the following three research questions:

1. How do consumers perceive the similarities and differences between boycott and buycott consumerism?

2. What motivates people to participate in boycott and buycott consumerism? a. What drives an individual to participate in boycott consumerism?

b. What drives an individual to participate in buycott consumerism?

3. In what way motivations can be meaningfully categorized for boycott and buycott consumerism?

This study adopts a qualitative approach. In-depth interviews with an existential phenomenology approach can better capture "first-person description" (Thompson et al., 1989, p.138) of boycott and buycott experiences from contemporary consumers.

\section{LITERATURE REVIEW}

Boycott is frequently practiced in the marketplace. It refers to a consumer's decision to punish private companies or countries by refraining from selective choices of products or brands based on social, political, or ethical considerations (Baek, 2010; Keum et al., 2004; Stolle et al., 2005). The central idea for boycott is to punish businesses that perform unfavourable behaviours through anti-consumption, hoping to force them to change unethical practices (Hoffmann et al., 2018). On the other hand, buycott describes consumers' collective actions that attempt to encourage shoppers to buy the products or services of selected companies in order to reward them for actions that are consistent with the goals of the activists (Friedman, 1996). It is considered as a positive approach as the behavioural consequence it advocates is about consumption, instead of anti-consumption (Friedman, 1996). Boycotts usually take place as a part of a structured organization, whereas buycott is easier to implement as it can be easily incorporated into day-today activities (Micheletti, 2004; Neilson, 2010).

A few studies have comparatively examined boycott and buycott consumerism. Findings show that both types of consumerism are grounded on political, ethical, or environmental motivations (Yates, 2011), but differ on the socio-demographic profile and the self-interest of consumers that participate in each type of activity (Baek, 2010; Hoffmann et al., 2018; Kam \& Deichert, 2019; Neilson, 2010). Specifically, boycotts, compare to buycotts, are more prevalent among consumers with higher education and income level, and are more likely to take place with male consumers (Baek, 2010). Buycotters, in contrast, are mainly females (Neilson, 2010). They show more trust towards others and are more likely to believe in marketing communications that highlight companies' ethical practices (Neilson, 2010). While pursuit of hedonism motivates individuals to buycott, a strive for voluntary simplicity increases consumer willingness to join boycott (Hoffmann et al., 2018). Finally, buycotters display a more informal learning style as opposed to boycotters (Copeland, 2014), where they selectively choose to learn about products or companies supporting values that are consistent with theirs (Zukin et al., 2006).

While there is some discussion on the similarities and differences between boycott and buycott, more research is still needed to distinguish these two types of consumerism and offer brands and companies insights on how to appropriately respond and address consumer concerns. To extend prior research that 
differentiates boycott and buycott mainly on participants' socio-demographic profiles, we would like to show how the motivational factors to the two types of consumerism align and differ.

\section{Motivational Factors for Boycott Consumerism}

The motivational factors pertaining to consumer boycott can be classified into four categories: individual-level, boycott specific, societal, as well as firm/market factors.

At the individual level, consumers usually perceive boycott participation to express individuality and boost self-enhancement. They try to enhance self-esteem and avoid a feeling of guilty by anti-consuming products from unethical brands (Klein et al., 2004; Kozinets \& Handelman, 1998). In addition, they may also use boycott to convey negative emotions, such as anger, displeasure, and outrage, towards target companies for their unethical conducts (Brennan \& Lomasky, 1993). Further, consumers are more motivated to participate in boycott if they are made aware that the target brand's unethical conduct goes against the value they are highly connected to (Garret, 1987; Yuskel, 2013). While people may feel satisfied through boycotting, they are also aware of and bear the costs associated with constrained consumption (Friedman, 1985; 1991; 1999; Garrett, 1987; Klein et al. 2004; Sen et al., 2001).

As to motivational factors that are unique to boycott, success rate is one of the most important determinants (Friedman, 1985; 1991; 1999; Klein et al., 2004; Sen et al., 2001). Any factor that implies the boycott's success likelihood is motivational to consumers. For instance, consumer participation interest is higher when the pro-boycott message has a "success" compared to a "failure" frame (Sen et al., 2011) and when the boycott leaders are more credible (Garrett, 1987). However, if boycott is associated with distrustful entities or accompanied with information on potential harm it may induce, consumers are found carefully weighing the pros and cons of participation and then make decisions (Klein et al., 2004; Yuskel, 2013).

Since boycott is a collective action, societal factors, such as pressure from friends and families, are quite influential to boycott decision. Sen et al. (2001) studied consumer boycott in the context of social dilemma and found that participation was higher if consumers were more susceptible to normative influences from the reference group. In addition to social compliance, consumer intent to seek for social changes also motivates their participation in boycotts. Finally, at the firm level, consumers are found more likely to join in boycotts if they perceive a firm's action as egregious (Klein et al., 2004).

\section{Motivational Factors for Buycott Consumerism}

Slightly different from boycott consumerism, the motivational factors for buycott are from individual, societal, and firm/market aspects.

At the individual level, consumer buycott is mainly induced by personal values (Friedman, 1996; Micheletti \& Stolle, 2008; Yates, 2011). Potential buycotters usually support causes related to environmental protection, animal rights, and ethical production. The consistency between consumer and brand values encourages consumer support of the brand. Unlike boycott, a venue for consumers to express negative feelings, buycott encourages consumption from socially responsible companies and thus offers enjoyment and pleasure that consumers pursue.

Individuals who buycott usually have great trust in the institutions and associations (Neilson, 2010), thus social capital is an important societal determinant to consumer buycott. Finally, a firm's practices on corporate social responsibility influences consumer buycott decisions (Bandura, 1969; 1988; Friedman, 1996).

In sum, extant literature has identified various motivational factors to consumers boycott and buycott. Since most papers focus on either boycott or buycott, there is a need to examine these two types of consumerism comparatively in one study to understand how individuals make decision between them, the research gap we would like to address in this paper. 


\section{RESEARCH METHODOLOGY}

We adopted an existential-phenomenology approach to our investigation. This approach helps to understand individuals from the environment they live in (Heidegger, 1962; Thompson et al, 1989), and allows for the first-person description of the experience. Specifically, we employed in-depth interviews to learn how individuals make meanings out from the boycotting and boycotting experiences (Seidman, 2013). We recruited fifteen participants from a city in Southern Ontario. Twelve out of them were students, and the other three were working professionals. The average age of the participants was twenty-three. Interestingly, only one male participant signed up for the study and the remaining fourteen interviewees were females. This gender ratio is consistent with previous research suggesting that women play a more active role in boycott and buycott participation as opposed to men (Lorenzini \& Bassoli, 2015; Stolle et al., 2005).

Interviewees were recruited via email, recruitment poster, or through personal connections. Upon sign up, they were requested to fill up a short survey asking about their previous boycott and buycott experiences. We excluded participants if they had ever participated in any activities that supported or avoided a brand for social, ethical, environmental, political, or animal welfare reasons. Participants who had some boycott and buycott experiences were contacted for a follow-up Zoom or Skype meeting. All the interviews were one on one and lasted around one and a half hours. Each interviewee was compensated with a \$20 Amazon e-gift card for the participation. Before the interview started, we explained to the interviewees the topic and the purpose of the study. We asked questions on socio-demographics (e.g., gender, age, education level) at the beginning of the interview.

We adopted a three-interview procedure (Schuman, 1982). In step one, we asked questions probing participants' past boycott and/or buycott experiences. Then, we requested participants to particularly talk about their thought processes when considering participating in boycott and buycott activities. Finally, we asked them to compare their own boycott and buycott experiences and summarize for similarities and differences. This three-step interview procedure allows participants to thoroughly reflect and reconstruct their past experiences.

Interviews were audio-recorded and transcribed. The interviews were first transcribed using computerbased word-processing software. Then, we reviewed the transcriptions for errors. The fifteen interviews provided a significant amount of dataset with 229 pages of transcriptions. Each interview transcription ranged from 12 to 21 pages. We highlighted relevant and important passages in transcriptions in order to shape the material into a sharable and interpretable form (Miles \& Huberman, 1984). We then adopted a two-phase procedure to identify common themes among transcriptions (Thompson et al., 1989). With guidance from our research questions and prior findings, we first compiled relevant quotes from the interviews under different categories. Next, common themes/patterns were distilled, combined, and compared within and across participants. At the final stage, we organized all the refined themes within prespecified categories.

\section{RESEARCH FINDINGS}

We report the study findings in three sections. First, we will provide a summary of consumer boycott and buycott experiences collected from the interview. Next, we present and compare how interviewees perceive the similarities and differences between boycott and buycott experiences. Finally, we discuss the motivational factors and corresponding contexts, unique to the two types of consumerism.

\section{Respondents' Consumer Boycott and Consumer Buycott Experiences}

The 15 in-depth interviews resulted in a total of 45 boycott and 35 buycott experiences. On average, each interviewee talked about 3 boycott and 2 buycott experiences. In line with prior research (Everard et al., 2016; Hoffman et al., 2018), societal concerns are the main cause of consumer boycott and buycott participation. Specifically, interviewees discussed a total of 29 experiences supporting environmental protection, 25 experiences advocating animal rights, and 23 experiences raising human rights concerns. 
Further, the environmental protection concern consisted of topics on plastic and paper waste, water resource maintenance, gas emission, and clothing waste. Animal rights concerns encompassed issues on animal torture or captivity, such as using animal furs for clothing or product testing on animals. Lastly, human rights concerns were mainly about unfair employee treatment, the use of child labour, women rights protection and gender equality. Interestingly, the interviews also captured some consumer experiences that were rarely discussed in prior boycott and buycott research, such as four buycott experiences about supporting local economy by purchasing locally produced products, and three experiences driven by personal health concerns and religious beliefs. Surprisingly, we found only a few mentions about boycott and buycott participation that was induced by political concerns or product quality issues.

The targets of boycott and buycott ranged from multi-million companies to small local stores across various industries. In general, boycott targets were mainly big corporations, such as Starbucks, GAP, Victoria's Secret, and Canada Goose, to list a few, while majority of the buycott targets were Ontario-based small businesses, such as Planet Bean Coffee, Lucky Iron Fish, and AreoGarden.

\section{Respondents' Different Perceptions of Boycott and Buycott Consumerism}

Respondents indicated three major perceived differences between boycott and buycott consumerism based on their consumption experiences.

\section{Boycott/Buycott - An Act of Avoidance Versus an Act of Approach}

Almost all the interviewees considered boycott and buycott as two distinct types of consumerism. Some of them clearly mentioned that boycotting is to avoid consumption but buycotting is to support businesses with individually or socially desired practices. This understanding aligns with the avoidance and approach characteristic of boycott and buycott. For example, one participant mentioned that "they are the opposite [actions] because [with] boycott you stop or avoid products/brands and buycott is that you support and endorse products/brands" (Interview \#1). Further, interviewees labeled boycott as being "negative" but buycott "positive". They explained that this valence difference was because boycott is in response to a company's unethical practices, whereas the target of buycott has positive publicity for socially responsible initiatives. Therefore, they chose to join a boycott to punish one company, but a buycott to reward another. Interviewees also mentioned that they tried to vent negative feelings, such as outrage, disappointment or anger, through boycotting, but often experienced positive emotions, like happiness, pride and empowerment, when participating in boycotting. This quote provides an example: "I would say that my emotions definitely change. For buycotting, it's definitely more of a positive experience for me. Where boycotting is just more of a negative and it's just like there's more anger and frustration." (Interview \#13)

In sum, consumers view boycott and buycott as different actions. They express concerns and disagreements through boycotting in responding to brands' unethical practices, but they buycott to support ethical brands and gain enjoyment and pride by doing so.

\section{Information Required for Boycott and Buycott Decisions Differs}

Interviewees acknowledged that the information required to make decisions on boycott and buycott would differ in terms of volume and content quality. With boycotting, participants mentioned that their decisions to exclude unethical brands from consideration set were often made fast. Information about the boycott target usually came from indirect sources, such as news from social media. Interestingly, they rarely validated the information they received unless the boycott target was a brand that they were highly associated with. Two participants, for example, stated that:

\footnotetext{
"Like the Canada Goose thing and the same with that Makeup Forever brand, I kind of just heard one or two things about it and I was like, okay I choose to not support that product." (Interview \#13)
} 
"For instance, with boycotts if I decide to boycott MAC, just reading that they tested on animals then I'm just done with that company. I cross them off and I'm like, hey, I won't shop there." (Interview \#4)

Nine out of fifteen participants, however, indicated that they did a more careful information search before participating in buycotts. One reason is that buycott encourages consumption from ethical brands, which usually induces high monetary costs. As a result, sufficient information is required for an informed decision. For instance, one interviewee explained that:

"Buycotting is like I have to actually use my money, so when it comes to using my money, I have to think about the initial purchase may be a little bit risky because you're using your money to buy a certain product." (Interview \#9)

In addition, consumers are more motivated to do information search for buycott since they see it as a type of hedonic behaviour (Hoffmann et al., 2018). Participants mentioned that they actively searched for information from company websites, social media, and friends to help justify their decision of buycotting. They preferred to read more details about the company's ethical practices before making the decision. For example, the following interviewees mentioned that:

"A lot of it was from their websites, so looking about them online and reading about their policies, signing up with their newsletters where they send out information via email every so often about how they run their operations. A lot of these places are very proud of their operations, so they advertising their store like what they do. So it's like physically going in the store and reading the posters on the wall and what they do in store. (Interview \#15)

"Buycott behaviour I will do more research and be more eager to learn about the cause. ... For instance, ... for a local company, if I learn about them and I'll probably do a lot more research to learn more about them and think of different ways that I can support them. So I think with buycott it definitely is kind of more research and learning involved." (Interview \#4)

Overall, consumers make quick decision on boycotting, but spend much more time and effort to validate information collected and help justify their boycotting decisions.

\section{It Is More Challenging to Participate in Boycott Than Buycott}

Interviewees indicated that participation in boycott (versus buycott) is more challenging. It is very difficult for consumers to stop purchasing brands that they have built a relation or established a consumption habit with. One interviewee, for example, expressed that it was a hard decision for her to boycott Forever 21 as she had been a loyal customer of this brand.

"When I previously purchased from Forever 21, I loved their clothing. So now when you hear about poor ethical decisions, they're making it really hard. Part of you just wants to pretend you didn't hear it and just still purchase from that brand because you love the product." (Interview 10)

On the other hand, the decision on buycott participation is relatively easier to make because of the positive attitudes and emotions associated with the action. One interviewee said that "it's easier to buy products because you like it" (Interview \#6). 


\section{Motivations for Boycott Consumerism}

In line with prior literature, three categories of motivational factors emerged from the interview data. At the individual level, consumers participated in boycott for self-enhancement purposes or to resolve negative emotions. Boycott specific factors, such as perceived efficacy and counterarguments associated with boycott, also motivate consumer participation. Finally, societal factors consist of motivational elements from society, friends, and families.

\section{Individual Level Motivational Factors}

Intrinsic Benefits of Self-enhancement and Emotional Expressions. More than half of the interviewees stated that joining in boycotts was a way to help them feel good about themselves. One interviewee said that boycotting Forever 21 helped to show her moral identity and the care she had for society.

"I feel like it supports my own identity as a person that is moral and cares about the world or at least cares about more things than just myself. Because if I think that I am a good person who cares about the environment or whatever it is that I care about and then I go to a store that very clearly does not, that just creates cognitive dissonance for me. Right? And so I suppose what I get out of is just a reinforcement of the fact that I am a decent person at least." (Interview \#1)

This finding supports the notion that consumer boycott is a personal rather than a communal action (Kozinet \& Handelman, 1998), as it relates to the boycotter's psychological gains or losses. Consumers are motivated to maintain or improve their self-esteem by either consuming desired brands or staying away from brands that are incongruent with their self-identity (Baumeister, 1998; Englis \& Soloman, 1995; Grubb \& Grathwohl, 1967; Hogg \& Banister, 2001; Sirgy, 1982). Boycotting thereby allows consumers to feel "free from guilt", differentiate themselves from others, and boost self-esteem (Kozinets \& Handelman, 1998; Makarem \& Jae, 2016).

Consumers also engage in boycott to express or vent the negative emotions they experience due to brands' unethical practices or the value mismatch between brands and themselves. Interviewees discussed various negative feelings they've encountered, such as anger, frustration, betrayal, and disappointment with the boycott target. One interviewee, for example, mentioned that:

"disappointment that I don't really know their goals or if they're more focused on making money and having that monetary benefit instead of the greater good" (Interview \#11).

These intense negative emotions are more likely to arise with boycotters who used to be emotionally affiliated with the target brand. This finding on negative feeling expression is consistent with prior working (Ettenson \& Klein 2005; Friedman, 1999). By expressing negative emotions via boycotting brands, consumers obtain better mood management (Makarem \& Jae, 2016).

Resource Capacities. Stolle et al. (2005) noted that one fundamental requirement for political consumerism is consumer ability to make consumption decisions. Four interviewees mentioned that when they were younger, they were unable to choose what products or brands to purchase as parents were the primary decision maker. That is to say, age is an important demographic factor that can affect boycott participation. One participant, for example, commented that "I think when I was younger, Ijust ate whatever my parents gave me" (Interview \#14).

In addition to age, education level and economic status are also relevant to boycott participation, as these two factors are also important indicators of consumer ability in making decisions. Some interviewees expressed that even though they were made aware of a cause or a company's unethical practices, they were not well educated or had sufficient knowledge to evaluate the information to make the decision. For example, an interviewee mentioned: 
"I think I always had these beliefs, but I didn't really even think about eating only kosher meat till I went to University. I would honestly say I feel like when I got into university, I start learning more about these reasons like obviously child labour and bad factory operations are bad, but I just started learning more and more about it and I realize how awful and unethical even dangerous this is gonna be." (Interview \#12)

Consumers often search for ethical substitutes once they decide to boycott. But if the price of the substitute brand is higher, then only high economic status consumers is able to switch brand. Thus, consumer economic status can predict boycott participation. The example below illustrates that ethical substitutes are usually more expensive due to the fair wages paid on labour, which might prevent consumers from boycotting the brand they originally used:

"The companies that you want to support are doing good and they're going to cost more because they're putting the effort and thought into making sure there's fair wages ...... That always comes with a price even if I try to buy more products that I know from smaller companies, but they tend to be more expensive." (Interview \#14)

In sum, age, education level, and economic status are important drivers to boycott participation. Higher education level allows consumers to access and comprehend information easier (Yates, 2011). Economic status is a key determinant as ethical substitutes are usually more expensive. Our findings corroborate with prior literature suggesting that civic and political participation require resources like time, money, communication and organization skills (Brady et al., 1995; Yates, 2011).

Costs of Boycott. We also find that the boycott decision is contingent upon costs associated with boycotting. The higher the costs, be it monetary or psychological, the less likely people would boycott a brand. In particular, interviewees mentioned two types of costs, the availability of substitutes and consumer preference for the boycott target (Braunsberger \& Bulcker, 2011; Klein et al., 2004; Sen et al., 2001). Consumers are less willing to boycott if their preference for the boycott brand product is high (Sen et al., 2001). More than half of the interviewees expressed that participating in boycott restricted their consumption pattern, especially if the boycott target was a frequently purchased brand. For example, one interviewee mentioned that it was tough for her to stop purchasing from Bath \& Body Works because she had been using this brand for years. That being said, she also mentioned that the care she had for the environment overcame the costs, and thus she decided to forgo the brand.

"I did think it was hard because I still like their products, so making that decision kind of put my values ahead of my likes and wants as a consumer was difficult. I really like their candles specifically and I still like them. I still think they smell great and they're great prices and they're great presents for people." (Interview \#15)

Several participants expressed the challenge with substitute search. However, boycotters were all eventually successful in finding substitute brands, thereby diminishing their negative feeling of sacrificing. Interestingly, as time went by, choosing substitute brands became a second nature for most consumers.

\section{Boycott Specific Motivational Factors}

Perceived Efficacy. Half of the interviewees believed that their participation in boycott would generate a significant and positive impact, whereas the other half thought more work would need to be done to achieve the goal for boycotting. Those who believed in the effectiveness of boycott discussed two approaches through which their action could make an impact. First, they believed that their action of boycotting would perhaps inform and educate other consumers. For example, an interviewee considered her action of avoiding certain meat brands would raise others' awareness. 
"I think that more than me individually making an impactful difference, but my choices other people see, so without me even having to have a conversation with somebody, they might notice that I'm not eating meat and then it sparks a conversation. It kind of sparks that conversation so more than just my choice to not purchase from those companies as making a difference, but when other people ask me about that, I'm able to share it with other people and hopefully they see that maybe they want to make those same decisions or maybe not but just I think it's a ripple effect." (Interview \#10)

Second, interviewees trusted that their brand switching behaviour would urge or even pressure the boycott target to fulfil the required social responsibilities by adjusting business practices.

"I think it's effective because like I said before everyone has purchase power. I guess it's kind of you can consider it as a vote. You put your money towards a brand and that's you voting for that brand, so if enough people do that then I guess [it's like] win the election. So other brands will kinda learn from that brand and I believe purchasing power does affect the way brands will operate and will be forced to change. Kind of look at what's not working and change to something that is working based on the needs and the wants of the people." (Interview \#11)

In contrast, the other interviewees believed that more actions are still in need to achieve the boycott goal. Not only the number of people that engage in boycott is determinative to its success, but the selection of boycotting venues is also important to achieve the goal. Boycotting a brand silently is not enough to make the change. The central idea of boycotting is to raise attention; therefore, making boycott more public such as being vocal and active on social media and/or expressing concerns more directly to the boycott target would be better approaches. The quote below provides an example:

"I understand that just because you avoid a company doesn't mean that they're changing anything. Like if I really wanted them to change, I should be sending letters and trying to talk to people in the Tim Hortons brand and actually express my concern. Whereas like when you're silent and you're just not shopping that's not always the most effective way to express your opinion." (Interview \#15)

Some interviewees explained that the managers from the boycott target may be aware of the boycott but do not know the exact reason that leads to it. One interviewee stated: "It wouldn't show the message why I stop buying." (Interview \#15). Indeed, even when consumers avoid purchasing from a brand due to its use of child labour, the management team might think the sales reduction is caused by the store environment. Thus, if boycotters could express to brand managers their reasons for boycotting, this may help brands to better improve ethical practices.

Our findings confirm that one main motivation to boycott participation is the perceived success rate of boycotting (Klein et al., 2004; Mahoney, 1976; Sen, et al., 2001). In other words, consumers are more willing to boycott if they feel their actions could make a difference and pressure companies to make changes (Sen, et al., 2001).

The Role of Counterarguments. Some counterarguments may arise to prevent consumers from participating in boycotts. One of the counterarguments is that boycotting may cause unintended harm to employees and businesses. To counterbalance this argument, consumers usually engage in a thorough comparison between the pros and cons of boycotting at both individual and societal level to justify their decision. For instance, one interviewee mentioned that:

“Well, number one I'm sure there's a lot of employees and staff that don't really have the same values as the company that worked for them, so by not supporting them I could be taking away the business or potential jobs. Also, with Amazon particularly, they do resale 
other brands, so if I'm not supporting them, I'm also having these impacts on these other independent sellers. And the stakeholders too. They aren't really associated with the company's decisions. I do feel like I'm impacting them unintentionally.” (Interview \#8)

Another counterargument is that besides unethical practices, the brand may have also done positive initiatives in the past. In this case, consumers need to weigh the impacts of positive and unethical practices to make a final decision. For example, one interviewee expressed that:

"I do have a lot of counterarguments because a lot of times these big companies are doing other positive things in addition to the negative impacts. So I feel like by abandoning and not supporting them at all, I might be not supporting these positive aspects as well. So in a way, I do feel like I am missing out on that. Could they be avoided, or could the company have done anything about it? And if the answer is yes, and they could have done it then that's when I start boycotting them. So I do find myself avoiding or boycotting those brands but it's mainly if the companies can do something about the problem then that's when I started boycotting them." (Interview \#8)

Majority of the interviewees mentioned that they have encountered counterarguments when deciding whether to boycott a brand. However, most of them still chose to participate in boycotting for the values and moral standards they upheld, regardless of the conflicting feelings they experience.

\section{Societal Level Motivational Factors}

Impact of Social Pressure. At the society level, we find that consumers often join in boycotts in order to gain approval from reference groups or form a good impression in front of them. A person often use reference groups to guide their behaviour in specific situations (Childers \& Rao, 1992). For example, one interviewee mentioned:

"I know there are people in my life that share the same beliefs and I have friends who are very much supporting Aerie, so I feel like I'm going against that if I were to support something like Victoria's Secret. So I would say there is a little bit of social pressure from other people in my life that have that same goal and vision." (Interview \#10)

Interestingly, two interviewees indicated that while they did not feel pushed to join in boycotts, they felt pressured to maintain the boycott behaviour once they started. The following comment from one interviewee indicated that boycotting is a conscious effort that urges consumers to keep making such as monetary sacrifices (e.g., higher price).

"I don't think that there is a social pressure though for me to have to boycott brands or to feel like I should. [But] I mainly feel that there is a social pressure for me to keep that up. And because if I start shopping at the same brand that I just boycotted then other people are going to think it's okay to boycott a brand and then just keep supporting them and have no impacts on." (Interview \#8)

That is, besides the individual level motivational factors, consumers who are susceptible to normative social influences are also more prone to boycott. People who are more susceptible to peer pressure are more likely to comply with social expectations (Fisher \& Ackerman, 1998).

\section{Motivations for Buycott Consumerism}

Unlike boycotting, the motivational drivers of buycotting were mainly captured at the individual and societal level. 


\section{Individual Level Motivational Factors}

The Pursuit of Hedonism. At the individual level, the pursuit of hedonism has emerged as the main motivational driver for consumer buycott decisions. Buycotting is usually associated with hedonism because consumers are able to align their personal consumption with values and moral obligations they uphold (Hoffmann et al., 2018). In other words, buycotting allows consumers to seek pleasure and enjoyment in shopping while also demonstrating their care for the society. One interviewee mentioned that buying from a second-hand store and consuming drinks that used recyclable packaging made her feel happy and helped her connect to the causes she stood for:

"I'm getting pleasure out of it. Like I am making a good impact in the world or preventing waste in other areas of environmental waste." Interview \#14.

More specifically, two sub-motivational factors have emerged under the hedonistic feature of buycott. First, participants mentioned that they did not feel sacrificing, but instead thought they were benefiting from buycotting brands. One interviewee, for example, stated that he gained health benefits by consuming the organic and local produce:

"I feel like I am gaining like when I buycott and decide to purchase something good for you, healthy and organic then I feel like I am not sacrificing anything” (Interview \#5).

The second sub-motivational element is the positive emotions experienced by buycotters. Ten out of fifteen interviewees expressed positive feelings when they joined buycott. Words like feeling "good", "accomplished", "valued", "satisfied", and "proud" were frequently mentioned by interviewees when they were describing buycotting experiences. In addition to these positive feelings, interviews also mentioned that they achieved self-enhancement through buycotting. One participant said that purchasing from certified local B corporations helped her to build psychological gain towards herself. She also felt being appreciated as the values that meant a lot to her were also supported by the brand.

"I feel very accomplished and satisfied knowing that there's not very much consumer dissonance." Interview \#8).

To conclude, buycott provides an opportunity for consumers to express value and moral obligations through consumption. It is seen an enjoyable and pleasing experience for most consumers who participate.

The Cost of Buycotting. Besides benefits, consumers also consider costs when making a buycott decision. There are two types of costs that can prohibit consumers from supporting a desired brand. The first is price. More than half of the interviewees mentioned that purchasing products with better ethical standards induces higher costs. For example, some of them described that "I am sacrificing some of my money" (interview \#5); "with clothing and makeup, it might be more expensive" (interview \#14); and "the main one would be higher cost" (interview \#15). Although participants were aware of a higher price, they were still willing to pay more to buycott a brand as they believed that this action would offer long-term rewards. For example, one interviewee said that:

"I guess it's like the higher cost comes with a higher reward. I think that's kind of what I tell myself is it might cost more to support this company like maybe this coffee isn't as cheap as Tim Hortons is, but the benefits of supporting them and supporting our local economy and staying by my morals outweigh those costs. So I feel like I can justify the higher cost more." (Interview \#15)

Another interviewee described a boycotting experience with local coffee stores as being "higher costs come with a higher reward". The interviewee thought her action of shopping at local coffee stores would help to reduce the waste generated from coffee cups, and thus the action was worthy of the costs. 
Loss of convenience is another type of costs that was mentioned in interviews. Some participants conveyed that because many buycott targets were smaller organizations, the inconvenience of finding these stores often prevented them from buycotting. For example, one interviewee wished she could get coffee from a local coffee shop more often but purchasing from Starbucks was a much convenient choice for her. However, to ease the feeling of guilt for not boycotting the local coffee shope, she tried to engage in other sustainable actions, such as using reusable containers.

"It's definitely less convenient. It's like right in my building so sometimes I would just be like it could be raining or it was like a little cold and so I would have to walk two minutes down the street to the coffee shop or I would stay within my building and if I needed a coffee quickly, I could justify by just getting Starbucks.” (Interview \#3)

Neilson (2010) reported that consumers usually make conscious efforts in support of buycotts. They make sacrifices on few choices of selection, loss of convenience, and higher price to support desired business practices. But boycotters use different ways to overcome the various costs and convince themselves to move away from organizations with unethical practices.

\section{Societal Level Motivational Factors}

Social Capital Trust Level. Social capital refers to shared values and understandings in a society, which enables individuals and institutions to trust each other (Bourdieu, 1983; Coleman, 1988; Neilson, 2010; Putnam, 2000). Social capital facilitates and motivates political consumerism in two ways (Neilson, 2010). First, people who believe in information on political consumerism are usually more likely to respond to boycott/buycott events. Second, the shared trust in a group leads political consumers to believe that the boycott/buycott activity they participate is likely to succeed. We find some supporting evidence about the role of social capital in motivating buycotts.

First, consumers are more likely to trust companies that show a willingness to sacrifice profits for being ethical and moral. One participant mentioned that she trusted and respected independent small coffee shops more than Starbucks because these small shops are dedicated to taking more ethical initiatives:

"I trust immensely simply because I know for a fact that it costs more money to do these things. Like eliminating straws, it costs them more money to buy these paper straws and they choose to put the environment ahead of their profits. If Starbucks doesn't have a great day and sales for a month, it's not closing down but that could be really detrimental to an independent coffee shop. So I think the fact that they have more to lose and they're the ones who are doing it first and not that they're both doing it first, but they're the ones who are setting the example. I have a lot of trusts and a lot of respect for independent coffee shops for doing that." (Interview \#3)

Second, many interviewees expressed their trust in smaller businesses for their transparencies. Three participants explained that smaller businesses they supported were more transparent with their operation and production. Interestingly, they also noted that it was easier to make personal connections with the owner or the employees of small businesses, which allowed them to know more about the companies' ethical/moral initiatives. One interviewee mentioned that:

"You can directly talk to the store owner, but if you go to like Walmart, good luck trying to talk to the CEO. I trust them because I know how their initiatives and what they care about is genuine. Whereas large organizations at the end of the day all they care about is making money, which like small owners too. That's how you make a profit but they still have a little bit of humanity to them whereas large organizations don't." (Interview \#1) 
Additionally, several participants discussed that they preferred to obtain information about buycott targets by checking their own websites or by visiting the stores directly. A participant said that they felt the first-hand information collected from the buycott targets was more credible than that obtained from other platforms:

\section{"I would trust definitely just because I could get more of my decision and like I can see it firsthand. I'm seeing their advertisements and I'm making that decision myself." Interview \#7}

While participants indicated a higher level of trust in buycott targets, a few interviewees suggested that they would keep follow the target's future actions to ensure it being continuously socially responsible.

\section{GENERAL DISCUSSION}

In this study, we aimed to further our understanding of buycott and boycott consumerism. Three core areas that differentiate boycott from buycott emerged from the in-depth interview, goal orientation (avoidance vs. approach), information learning style, and the ease of participation. Specifically, consumers view boycott as a response to negative initiatives to express their concerns and disagreements, whereas buycott as a practice to demonstrate their support of ethical brands, a find that is consistent with prior literature (Baek, 2010; Hoffmann et al., 2018; Kam \& Deichert, 2019; Micheletti, 2003; Micheletti \& Boström, 2014; Neilson, 2010; Stolle \& Micheletti, 2013). Second, consumers spend less time and effort collecting information to justify their boycott decisions but engage in extensive information search before participating in buycotts. That is to say, buycotters usually learn more information about the targets than boycotters (Copeland, 2014). Finally, consumers find it's easier to decide on buycott than boycott participation because engaging in the former practice is more pleasant and satisfying. These findings highlight the fact that boycott and buycott are two distinct anti-consumerism initiatives.

To complement the understanding of the distinct nature of the two types of consumerism, we also identified the various motivational factors and corresponding contexts that are collectively and uniquely related to boycotting and buycotting (see Table 1).

TABLE 1

MOTIVATIONS AND CORRESPONDING CONTEXTS FOR THE TWO TYPES OF POLITICAL CONSUMERISM

\begin{tabular}{|l|l|l|}
\hline & \multicolumn{1}{|c|}{ Motivations for Boycott Consumerism } & \multicolumn{1}{c|}{$\begin{array}{c}\text { Motivations for Buycott } \\
\text { Consumerism }\end{array}$} \\
\hline $\begin{array}{l}\text { Individual level } \\
\text { factors }\end{array}$ & $\begin{array}{l}\text { Self-enhancement: self-esteem and guilt-free } \\
\text { Negative emotions: disappointment, anger, } \\
\text { frustration and betrayed } \\
\text { Resources required: education level and } \\
\text { economic level } \\
\text { Perceived Costs: Availability of alternatives } \\
\text { and preference for the boycotted product }\end{array}$ & $\begin{array}{l}\text { Pursuit of hedonism } \\
\text { Positive emotions: enjoyment } \\
\text { and rewarding } \\
\text { Perceived costs: price and } \\
\text { inconvenience }\end{array}$ \\
\hline $\begin{array}{l}\text { Boycott/buycott } \\
\text { specific factors }\end{array}$ & $\begin{array}{l}\text { Perceived efficacy } \\
\text { Counterarguments: Unintended harms and } \\
\text { conflicting marketing practices }\end{array}$ & $\begin{array}{l}\text { Social capital: generalized } \\
\text { trust }\end{array}$ \\
\hline $\begin{array}{l}\text { Societal level } \\
\text { factors }\end{array}$ & Social pressure from reference groups & \\
\hline
\end{tabular}

Our findings on the motivational drivers of boycotting not only corroborate the existing literature but also offer some new insights. Klein et al. (2004) found that counterarguments such as boycott induced 
unintended harm could refrain one from boycotting. Extending this literature, we reveal that consumers consider and weigh both the positive and negative practices a company does before making boycotting decisions. They usually hesitate to boycott brands that have behaved ethically and morally in the past. Different from studies that identified perceived efficacy of boycotts as an important driver for consumer participation (Friedman, 1985; 1991; 1999; Klein et al., 2004; Sen, et al., 2001), we show that even when participants thought their individual contribution could be minimal, they may still choose to participate to help boost self-esteem, reinforce their own moral standards, and vent out anger and outrage to the target brands.

The civic volunteerism model proposed that any type of political consumerism requires resources (Brady et al., 1995). We find that higher education enables consumers to assess and comprehend the information regarding brands' unethical practices, and a better economic status frees them from monetary concerns with boycott participation. Consumers also carefully evaluate costs associated with boycotts, not only the availability of substitutes and their preference for the boycott target would impact their decision (Braunsberger \& Bulcker, 2011; Klein et al., 2004; Sen et al., 2001). Price of the substitutes is also an important motivational factor. Finally, consumer boycott decisions are influenced by their level of susceptibility to normative social influences (Childers \& Rao, 1992; Sen et al., 2001). We find that consumers receive more pressure from reference groups instead of close friends and families. Even if they do not feel pushed to participate in boycotting, they carefully monitor the continuity of their behaviours due to social pressure.

On the other hand, consumers consider buycott as an approach to pursuing hedonism given the positive emotions associated with this practice (e.g., happy, accomplished and satisfied). In this study we find evidence that consumers do not think participating in boycotting as a hard decision but a proud investment as they are supporting ethical practices. Consumers that participate in buycott show a high level of trust in the society. Although they recognize there may be costs associated with buycotting, such as increase monetary costs and loss of consumption convenience, they justify the costs with long term positive impacts on the brands and industry.

\section{Theoretical Contributions}

Overall, through in-depth interview with real consumers, we show the similarities and differences between boycott and buycott, two frequently implemented and discussed contemporary political consumerism. We demonstrate that consumer boycott and buycott differ in terms of their goal orientation, information search and learning, as well as ease of participation. In addition, we identify motivational factors within their corresponding contexts that collectively and uniquely related to consumer boycott and buycott decisions. Specifically, the motivational factors can be categorized under three contexts: the individual level, societal level, and boycott/buycott specific determinants. While factors from all the three categories may help to predict boycott participation, only individual and societal factors are relevant to buycott decisions.

Furthermore, unlike previous studies that mainly utilized survey research, we use in-depth interviews to capture first-hand consumer boycott and boycott experiences and provide rich and vivid information about how consumers made decisions about boycotting and boycotting, their feelings during participation and their true understanding of the two types of consumerism. We not only provide evidence that supports prior literature but extend the literature by showing the nuanced differences between boycott and buycott and identifying their unique motivational factors within various corresponding contexts.

\section{Managerial Contributions}

From a managerial perspective, this study supports the proposal that companies need to recognize political consumerism as a trend and that consumers are well aware of the power of their consumption decisions (Kam \& Deichert, 2019). Thus, it is important for managers and policymakers to understand how and why consumers react to specific corporation practices. The experiences we collected from participants' boycotting and buycotting experiences imply that environmental issues, animal rights, and human rights are three major causes that consumers attend to. These findings call managers to design marketing strategies 
that are more targeted towards the identified causes to avoid consumer boycotting but encouraging buycotting. As certain individual characteristics can be used to distinguish boycotters from buycotters, a better understanding of target segments is important for managers to appropriately respond to consumer boycotts and buycotts. For example, consumers who are ready to restrict consumption are willing to translate their prosocial concerns into boycott actions, but people with hedonistic values are prone to buycott.

\section{Limitations and Future Research}

There are a few limitations that need to be noted from this search. Although this study provided sufficient insights that influence consumer's decisions to boycott and buycott, the interviewees are from one location in Ontario, Canada. The interviewees were all young adults mainly university students who were in their early or mid-20s. Future research could comprise of consumers from other parts of Canada as well as additional sociodemographic segment of consumers who are participants of boycott and buycott. Given that older adults contribute to more than half of the population in Canada (Duffin, 2020), thus researchers could focus on this consumer segment as well.

Second, several studies have shown that women, in general, are more likely to participate in political consumerism than men (Neilson, 2010; Yates, 2011). For this study, among fifteen interviewees, only one interviewee is male. In one way, the recruitment results indicated that women are indeed more active in political consumption and overall, this study captured mainly females' perspectives. Future research could focus on male political consumers. It would be interesting to compare whether gender plays the role of a motivator in boycott and buycott actions. Lastly, future research could empirically validate the results from this study. Particularly, using quantitative measurements to understand which factors are the most and the least predictive of the consumer's behaviour. This would provide more insights regarding how individual characteristics encourage boycott and buycott participation.

\section{REFERENCES}

Baek, Y. (2010). To buy or not to buy: Who are political consumers? What do they think and how do they participate? Political Studies, 58(5), 1065-1086.

Bandura, A. (1969). Principles of behavior modification. New York, NY: Holt, Rinehart, \& Winston.

Bandura, A. (1998). Self-regulation of motivation and action through goal systems. Cognitive Perspectives on Emotion and Motivation, pp. 37-61.

Baumeister, R.F. (1998). The self. In D.T. Gilbert, S.T. Fiske, \& G. Lindzey (Eds.), Handbook of Social Psychology. Boston: McGraw-Hill.

Bourdieu, P. (1983). Forms of capital. Handbook of Theory and Research for the Sociology of Education. J.G. Richardson (Ed.). Greenwood Press: New York.

Brady, H.E., Verba, S., \& Schlozman, K.L. (1995). Beyond SES: A resource allocation model of political participation. American Political Science Review, 89(2), 271-294.

Braunsberger, K., \& Buckler, B. (2011). What motivates consumers to participate in boycotts: Lessons from the ongoing Canadian seafood boycott. Journal of Business Research, 64(1), 96-102.

Brennan, G., \& Lomasky, L (1993). Democracy and decision: The pure theory of electoral preference. Cambridge: Cambridge University Press.

Childers, T., \& Rao, A. (1992). The influence of familial and peer-based reference groups on consumer decisions. Journal of Consumer Research, 19(2), 198-211.

Coleman, J. (1988). Social capital in the creation of human capital. American Journal of Sociology, 94(Suppl), 95-120.

Copeland, L. (2014). Conceptualizing political consumerism: How citizenship norms differentiate boycotting from boycotting. Political Studies, 62(S1), 172-186.

Crane, A., Matten, D., \& Spence, L.J. (2008). Corporate social responsibility, in a global context. In A. Crane, D. Matten, \& L.J. Spence (Eds.), Corporate Social Responsibility. Readings and Cases in a Global Context (pp. 3-20). Abingdon, UK: Routledge. 
Englis, B., \& Solomon, M. (1995). To be and not to be: Lifestyle imagery, reference groups, and the clustering of America. Journal of Advertising, 24(1), 13-28.

Ettenson, R.E., \& Klein, J.G. (2005). The fallout from French nuclear testing in the South Pacific: A longitudinal study of consumer boycotts. International Marketing Review, 22(2), 199-224.

Everard, M., Reed, M.S., \& Kenter, J.O. (2016). The ripple effect: Institutionalising pro-environmental values to shift societal norms and behaviours. Ecosystem Service, 21, 230-240.

Fisher, R.J., \& Ackerman, D. (1998). The effects of recognition and group need on volunteerism: A social norm perspective. Journal of Consumer Research, 25, 262-275

Friedman, M. (1985). Consumer boycotts in the United States, 1970-1980: Contemporary events in historical perspective. Journal of Consumer Affairs, 19(1), 96-117.

Friedman, M. (1991). Consumer boycotts: A conceptual framework and research agenda. Journal of Social Issues, 47(1), 149-168.

Friedman, M. (1996). A positive approach to organized consumer action: The "buycott" as an alternative to the boycott. Journal of Consumer Policy, 19, 439-451.

Friedman, M. (1999). Consumer Boycotts. New York, NW: Routledge.

Garrett, D.E. (1987). The effectiveness of marketing policy boycotts: Environmental opposition to marketing. Journal of Marketing, 51(2), 46-57.

Grubb, E., \& Grathwohl, H. (1967). Consumer self-concept, symbolism and market behavior: A theoretical approach. Journal of Marketing, 31(4), 22-27.

Heidegger, M. (1962). Being and Time. New York, NY: Harper \& Row.

Hoffmann, S., \& Hutter, K. (2012). Carrotmob as a new form of ethical consumption: The nature of the concept and avenues for future research. Journal of Consumer Policy, 35(2), 215-236

Hoffmann, S., Balderjahn, I., Seegebarth, B., Mai, R., \& Peyer, M. (2018). Under which conditions are consumers ready to boycott or buycott? The roles of hedonism and simplicity. Ecological Economics, 147, 167-178.

Hogg, M., \& Banister, E. (2001). Dislikes, distastes and the undesired self: Conceptualizing and exploring the role of the undesired end state in consumer experience. Journal of Marketing Management, 17(1-2), 73-104.

Kam, C.D., \& Deichert, M.A. (2019). Boycotting, buycotting, and the psychology of political consumerism. Journal of Politics, 82(1), 72-88.

Keum, H., Devanathan, N., Deshpande, S., Nelson, M.R., \& Shah, D.V. (2004). The citizen consumer: Media effects at the intersection of consumer and civic culture. Political Communication, 21(3), 369-391.

Klein, J.G., Smith, C., \& John, A. (2004). Why we boycott: Consumer motivations for boycott participation. Journal of Marketing, 68(3), 92-109.

Kozinets, R.V., \& Handelman, J. M. (1998). Ensouling consumption: A netnographic exploration of boycotting behaviour. Advances in Consumer Research, 25. J. Alba \& W. Hutchinson (Eds.), (pp. 475-480). Association for Consumer Research.

Kvale, S. (1983). The qualitative research interview: A phenomenological and a hermeneutical mode of understanding. Journal of Phenomenological Psychology, 14(2), 171-196.

Lorenzini, J., \& Bassoli, M. (2015). Gender ideology: The last barrier to women's participation in political consumerism? International Journal of Comparative Sociology, 56(6), 460-483.

Mahoney, J. (1976). The relationship of anticipated effectiveness, alienation, and value structure to planned participation in a national meat boycott. Psychology, 13(2), 39-47.

Makarem, S.C., \& Jae, H. (2016). Consumer boycott behavior: An exploratory analysis of twitter feeds. Journal of Consumer Affairs, 50(1), 193-223.

Micheletti, M. (2003). Political Virtue and Shopping: Individuals, Consumerism, and Collective Action. New York, NY: Palgrave Macmillan.

Micheletti, M., \& Boström, M. (2014). Political Consumerism: Consumer Choice, Information, and Labeling. Germany: Springer Netherlands.

Micheletti, M., \& Stolle, D. (2008). Fashioning social justice through political consumerism, capitalism 
and internet. Cultural Studies, 22(5), 749-769.

Micheletti, M., Oosterveer, P., \& Boström, M. (2019). The Oxford Handbook of Political Consumerism. New York, NY: Oxford University Press.

Miles, M.B., \& Huberman, A.M. (1984). Qualitative Data and Analysis: A Sourcebook of New Methods. Beverly Hills, CA: Sage.

Neilson, L.A. (2010). Boycott or buycott? Understanding political consumerism. Journal of Consumer Behaviour, 9(3), 214-227.

Neilson, L.A., \& Paxton, P. (2010). Social capital and political consumerism: A multilevel analysis. Social Problems, 57(1), 5-24.

Newman, B.J., \& Bartels, B.L. (2011). Politics at the checkout line: Explaining political consumerism in the United States. Political Research Quarterly, 64(4), 803-817.

Putnam, R.D. (2000). Bowling Alone: The Collapse and Revival of American Community. New York, NY: Simon \& Schuster.

Schuman, D. (1982). Policy Analysis, Education, and Everyday Life: An Empirical Reevaluation of Higher Education in America. Lexington, MA: DC Heath.

Seidman, I. (2013). Interviewing as Qualitative Research: A Guide for Researchers in Education and the Social Sciences (4th Ed.). New York, NW: Teachers College Press.

Sen, S., Gürhan-Canli, Z., \& Morwitz, V. (2001). Withholding consumption: A social dilemma perspective on consumer boycotts. Journal of Consumer Research, 28(3), 399-417.

Shah, D., McLeod, D., Kim, E., Lee, S.Y.M., Ho, S., \& Breivik, H. (2007). Political consumerism: How communication and consumption orientations drive lifestyle politics. The Annals of the American Academy of Political and Social Science, 611(1), 217-235.

Shaw, D., Newholm, T., \& Dickinson, R. (2006). Consumption as voting: An exploration of consumer empowerment. European Journal of Marketing, 40(9/10), 1049-1067.

Sirgy, M. (1982). Self-concept in consumer behavior: A critical review. Journal of Consumer Research, 9(3), 287-300.

Stolle, D., \& Micheletti, M. (2013). Political Consumerism Global Responsibility in Action. New York, NY: Cambridge University Press.

Stolle, D., Hooghe, M., \& Micheletti, M. (2005). Politics in the Supermarket: Political Consumerism as a Form of Political Participation. International Political Science Review, 26(3), 245-269.

Strømsnes, K. (2009). Political consumerism: A substitute for or supplement to conventional political participation? Journal of Civil Society, 5(3), 303-314.

Thompson, C., Locander, W., \& Pollio, H. (1989). Putting consumer experience back into consumer research: The philosophy and method of existential-phenomenology. Journal of Consumer Research, 16(2), 133-146.

Yates, L. (2011). Critical consumption: Boycotting and boycotting in Europe. European Societies, 13(2), 191-217.

Yuksel, U. (2013). Non-participation in anti-consumption: Consumer reluctance to boycott. Journal of Macromarketing, 33(3), 204-216.

Zukin, C., Keeter, S., Andolina, M., Jenkins, K., \& Carpini, M.X.D. (2006). A New Engagement? Political Participation, Civic Life, and the Changing American Citizen. New York, NW: Oxford University Press. 